\title{
Evaluation of Chia (Salvia Hispanica L.) Seeds Meal as a Source of Bioactive Ingredients
}

\author{
Osama, B.R. Mohammed ${ }^{1}$, Mona, H.H. Bekhet ${ }^{1}$, Amal , M. Abd El-Razek ${ }^{1}$ and Yehia, G. Moharram ${ }^{1}$
}

\begin{abstract}
The main aim of this investigation was to evaluate the meal of Egyptian chia seed (Salvia hispanica $\mathrm{L}$.) as a source of bioactive components comparing with the USA imported one. The results showed slight differences in proximate composition, dietary fibers components, nutritional value, total and HPLC separated simple phenolic compounds especially, caffeic acid, gentisic, rosmarinic and cteachin between meals of local and imported chia seeds. Both meals had nearly similar amino acids pattern, in vitro protein digestibility (IVPD) (66.5 - 66.9\%), computed- protein efficiency ratio (C-PER) (1.1 - 1.3) and biological value ( $C$ BV) ( $69.4-71.6 \%)$, high water ( $7.5-8.5 \mathrm{~g}$ water $/ \mathrm{g}$ meal), oil ( 5.1-5.3 g oil / g meal) holding capacities, good emulsification capacity $(52-55 \mathrm{ml}$ oil $/ 100 \mathrm{~g})$, poor foaming capacity and stability, high total (55.8-57.7\%), insoluble (48.2-53.3\%), neutral detergent (43-47.2\%) and acid detergent $(34.2-36 \%)$ dietary fibers. The antioxidant activity as determined by DPPH and ABTS methods was relatively higher in meal of the local than imported chia seeds. Dry fractionation of chia seed meal through 100 mesh sieve gave two fractions, one rich in protein (41.5$45.5 \%)$ and others high in neutral detergent $(86.5-90.7 \%)$, acid detergent $(49.01-54 \%)$ and hemicellulose (36.7$37.49 \%$ ) dietary fibers. Panelists accepted the physical and sensory properties of the biscuit products containing $5 \%$ of rich protein and high fiber chia seed meal fractions. Such results indicated the successful use of chia seeds meal as a source of bioactive ingredients in preparing functional food.
\end{abstract}

Keywords: Chia seeds meal, nutritional quality, phenolic compounds, functional properties, fractionation, biscuit.

\section{INTRODUCTION}

Protein content in a chia seeds (19-23\%) is higher than wheat $(\sim 14 \%)$, corn $(\sim 14 \%)$, rice $(\sim 8.5 \%)$, oats $(\sim 15.3 \%)$, barley $(\sim 9.2 \%)$ and amaranth $(\sim 14.8 \%)$ (Bresson et al., 2009 , Sandoval-Oliveros and ParedesLopez, 2013). It has a good balance of essential and non-essential amino acids (Ullah et al., 2016). Defatting and mucilage removing led to rise of chia seed protein up to $35.5 \%$. This protein was fractionated according to its solubility into $17.3 \%$ albumins, $52 \%$ globulins, $12.7 \%$ prolamins and $9-14.5 \%$ glutelins. It is free from gluten and can be digested by celiac disease patients ( Sandoval-Oliveros and Paredes-Lopez, 2013). The

\footnotetext{
DOI: 10.21608/ASEJAIQJSAE.2019.29935

${ }^{1}$ - Food Science and Technology Dept., Fac. of Agric., Alexandria Univ., El-Shatby, 21545, Alexandria, Egypt.

Received March 4, 2019, Accepted March 31, 2019
}

storage protein of chia seed was globulin. It was composed of two fractions with a molecular size ranged from 15 to $50 \mathrm{kDa}$. The first was with $11 \mathrm{~S}$ sedimentation coefficient and known as legumin like or $11 \mathrm{~S}$ globulins, and the second was with $7 \mathrm{~S}$ sedimentation coefficient and referred as a $7 \mathrm{~S}$ globulin or vicilin-like. Also, there was other one found in less proportion and known as 2 S-like protein (Ullah et al., 2016). According to Segura-Campos et al. (2013) and Orona-Tamayo et al. (2015) chia seed globulin protein provides a high concentration of biologically active peptides with antihypertensive and other important function. The in vitro protein digestibility of the defatted chia flour was slightly lower (77.5-78.9\%) than that of its protein globulin fraction $(82.5 \%)$ and higher than that of sorghum (59.1\%) and corn $(68.6 \%)$ (SandovalOliveros and Paredes- Lopez, 2013).. High fiber content of chia seeds meal may be behind the low of its in vitro protein digestibility (Vázquez-Ovando et al., 2010). Such fibers are low digestibility and low caloric content. It is not attacked by the stomach and small intestine enzymes and therefore reaches the colon undegraded (Prosky, 2001). Generally, there are no reports of antinutritive factors in chia seeds that could retard its in vitro digestibility such as presence of protease inhibitors.

Vázquez-Ovando et al. (2010) used screening process to fractionate chia seed protein meal into fiberand protein- rich fractions. The fiber rich fraction had high insoluble dietary fiber content, good water, oil and organic molecule absorption capacities. The protein rich fraction had high essential sulfur amino acids and nonessential amino acids as well as limited amino acids such as tryptophane and lysine. Capitani et al. (2013) showed that the chia seed meals with mucilage exhibited a statistically higher water holding capacity (WHC) than that of the meal without mucilage. The WHC of both meals was higher than that observed for canola $(3.90$ $\mathrm{g} / \mathrm{g})$, soybean meals $(3.28 \mathrm{~g} / \mathrm{g})$ and similar to that of linseed $(6.03 \mathrm{~g} / \mathrm{g})$ meals. Also, the chia seed meal with mucilage showed a low absorption of organic molecules and oil-holding capacity than meal without mucilage. Results of Vázquez-Ovando et al. (2013) indicated that the dry fractionated chia seed meal flour rich in protein 
had high emulsification activity (50-56\%) and can be considered a good emulsion stabilizer during preparing ice cream, dressing, chocolates, mayonnaise and other products. Foaming properties of the chia flour were poor and that may probably due to its an adequate unbalance between hydrophobicity and hydrophilicity and its low albumin relative proportion (10\%).

The defatted chia seed flour had $40 \%$ total dietary fibers (TDF), 5-10\% of which was soluble and formed parts of the mucilage (Ullah et al., 2016). Insoluble dietary fibers (IDF) was the main fraction with lignin as a main component, $39-41 \%$ of TDF. The other components of IDF were cellulose and hemi-cellulose (Pizarro et al., 2015).

Chia seeds are a promising source of natural antioxidants due to the presence of non hydrolyzed polyphenols, chlorogenic and caffeic acids and hydrolyzed polyphenols, myricetin, quercetin, kaempferol and flavonol glycosides. They are responsible of the antioxidant activity of chia (Ayerza $e t$ al., 2002). The phenolic compounds content in chia seeds ranged from 7.6 to $8.8 \%$ as a gallic acid equivalent (GAE) (Reyes-Caudillo et al., 2008). These phenolic compounds showed high antioxidant activity in the DPPH assay (85.3\%). The phenolic extract was effective in neutralizing more than $70 \%$ of the free radicals. They act as a radical sequestrators and hydrogen donors. Therefore, they able to lower the incidence of cardiovascular disease and to prevent the oxidation of unsaturated fatty acids (Michele and Myriam, 2014 and Ullah et al., 2016).

The main objectives of this study were; to characterize the Egyptian defatted chia seeds comparing with imported one, to detect its proximate composition, nutritional quality, functional properties, type and amount of its major antioxidant compounds using HPLC technique, in addition to its utilization in food purposes.

\section{MATERIALS AND METHODS}

\section{Materials}

Chia (salvia hispanica L.) seeds meal:- Two types of black chia seeds were used in this study. The first was imported from USA, 2016 harvest. It was purchased from one commercial retail at Alexandria city, Egypt in November 2016. The second was locally produced in one private farm at El-Haddadeen city, El-kalyobiya, Egypt, in November 2016. These seeds were locally produced by sowing the USA imported black chia, 2015 harvest, with $80 \%$ germination capacity at a seeding rate of 1.5 to $2 \mathrm{~kg} /$ acre. The seeds were grown in loamy soil in the period of November 2015 to April 2016. The seeds were not treated chemically prior to sowing and also with insecticides during growth. They were sown in drills with 5-10 $\mathrm{cm}$ deep in soil which has been leveled before cultivation. Before sowing, the soil was treated with super nitrate $(100 \mathrm{~kg} / \mathrm{acre})$ fertilizer. At sowing, the seeds were planted in raws with $10 \mathrm{~m}$ long. The crop was irrigated 4 times at a rate of $15000 \mathrm{~m}^{3} /$ acre. Rainfall was moderately occurred through end of December and first half of January and the mean of temperature was ranged from $18-24^{\circ} \mathrm{C}$ during growth of plant. All cultivation work was carried out manually. Seeds were manually harvested and the seed yield was $500 \mathrm{~kg} /$ acre. The harvested seeds were packed in polyethylene bags and stored under hygienic conditions. The cleaned dried chia seeds were ground in Wiley mill to pass through 60 mesh sieve before defatting with petroleum ether (b.p. $40-60^{\circ} \mathrm{C}$ ) in Soxhlet apparatus for $16 \mathrm{~h}$. as mentioned by Amato et al. (2015). The defatted meal was desolventized at $60^{\circ} \mathrm{C}$ in an air draft oven until solvent removal,50 min.

Food ingredients:- The following food ingredients were obtained from local market at Alexandria city, Egypt; $72 \%$ extraction wheat flour, refined sunflower oil, margarine, sugar, common salt, sodium bicarbonate and ammonium bicarbonate.

Chemicals:-Most of the chemicals used in this investigation were purchased from El-Gomhouria Pharmaceutical Company and El-Nasr Pharmaceutical Chemical Company, Egypt. The used reagents, solvents and phenolic standard compounds for HPLC analysis were bought from Sigma-Aldrich company (St. Louis, Missouri, USA).

Packing materials:- Aluminum foil, trays and polyethylene bags were purchased from local markets at Alexandria city, Egypt.

\section{Methods}

Physical methods:-Triplicate random samples of biscuit were weighed using Mettler Teledo AB 204 digital balance $( \pm 0.01 \mathrm{~g}$ sensitivity). The average of these triplicates was reported as biscuit weight. 10 biscuit pieces samples were used to measure their thickness, length and width by a digital micrometer with an 0.01 mm accuracy (Khattab, 2004).

Chemical methods:-The defatted chia seeds were ground in a willy mill to pass through 60 mesh sieve (250 microns), filled in glass kilner jars and stored at $4^{\circ} \mathrm{C}$ until analysis.

Proximate composition:- The chemical analysis of chia seeds meal was run in triplicate. Moisture content was determined by drying the samples at $130^{\circ} \mathrm{C}$ for $4 \mathrm{~h}$. as described by Guiotto et al. (2011). Total nitrogen was determined using the Kjeldahl method and crude protein content was calculated by multiplying the nitrogen content by factor of 6.25 (Nielson, 2010). Ash content 
was determined after pre-ashing in muffle furnace (Vulcan A-550) at $550^{\circ} \mathrm{C}$ until getting light gray ash and a constant weight was resulted. Crude fiber content was determined according to A.O.A.C. (2003) method via filter bags technology using Fiber analyzer (Ankom 200. Model No. A220, USA). Nitrogen free extract of chia seeds was calculated by difference.

Chia seed meal fractionation:- After extraction of oil, chia seed meal was milled to pass through $0.5 \mathrm{~mm}$ screen before fractionated by sifting for 20 min. using Tyler 100 mesh (150 microns) screen and a Ro-Tap1 agitation system according to Vázquez-Ovando et al. (2013) into two fractions; protein-rich fraction which passed through the 100 mesh and fiber rich fraction which retained in the 100 mesh. Each fraction was packed in glass jar and stored at $4^{\circ} \mathrm{C}$ until analysis.

Total (TDF), soluble (SDF), insoluble (IDF), acid detergent (ADF) and neutral detergent (NDF) dietary fibers:- They were determined in fat extracted chia seed flour and its fractions as mentioned in A.O.A.C. (2000). The sample was treated with heat stable amylase, amyloglucosidase and protease in an autoclave. An enzymatically undigested fiber (insoluble residue) was filtered, dried, weighted, ashed and reweighted to give the amount of insoluble dietary fiber (IDF). The digested fraction of sample was precipitated with ethanol, treated with amylase from porcine pancreas to remove soluble carbohydrates and protein then filtered and the resulted residue was dried, weighted, ashed and reweighted to give soluble dietary fiber (SDF). Total dietary fiber (TDF) was calculated as sum. of the IDF and SDF. Determination of NDF was based on refluxing the samples with hot solution of neutral detergent to measure the total cell wall materials. Meanwhile, estimation of ADF was based on refluxing of sample with hot sulfuric acid solution containing detergent to get a good measure of the cellulose and lignin.

Total phenolic content: - It was determined according to the procedure of Zilic et al. (2012) using FolinCiocalteau reagent and gallic acid as standard. One $g$ of defatted sample was extracted with $10 \mathrm{ml}$ methanol and shacked for $3 \mathrm{~h}$. in dark at room temperature $\left(25 \pm 2{ }^{\circ} \mathrm{C}\right)$. $100 \mu \mathrm{l}$ of the methanol extract was transferred into a test tube and the volume adjusted to $3.5 \mathrm{ml}$ with distilled water before adding $250 \mu \mathrm{l}$ of Folin-Ciocalteau reagent. The reaction mixture was kept in dark for $2 \mathrm{~h}$. before measuring the absorbance at $765 \mathrm{~nm}$ wave length using UV-Vis spectrophotometer, Laxco-Alpha1102, Suite.

Separation and determination of simple phenolic compounds by HPLC:- This was carried out according to Kim et al. (2006) with some modifications.
1)Extraction of phenolic compounds:- Extraction of phenolic compounds was done by weighing one gram of defatted chia seed flour in quick fit conical flask, adding $20 \mathrm{ml}$ of $2 \mathrm{M} \mathrm{NaOH}$, flushing the flask with $\mathrm{N}_{2}$ gas, replacing the stopper flash, shaking for $4 \mathrm{~h}$. at $1200 \mathrm{rpm}$ at room temperature $\left(23 \pm 2^{\circ} \mathrm{C}\right)$, adjusting the $\mathrm{pH}$ to 2 with $6 \mathrm{~N} \mathrm{HCl}$ and centrifugation at $5000 \mathrm{rpm}$ for $10 \mathrm{~min}$. The phenolic compounds in the obtained supernatant were extracted twice with $50 \mathrm{ml}$ of $1: 1(\mathrm{v} / \mathrm{v})$ mixture of ethyl ether and ethyl acetate. The organic phase was separated in separated funnel, concentrated under vacuum at $45^{\circ} \mathrm{C}$ by a rotary evaporator, re-dissolved in $2 \mathrm{ml}$ ethanol, filtered through $4.5 \mu \mathrm{m}$ milli pore filter (Gelman, Laboratory, MI).

2)Separation and determination:- $50 \mu \mathrm{l}$ of the resulted filtrate was injected in HPLC. Agilent type 11100 series (Agilent. Technologies; CA, USA). The apparatus equipped with solvent delivery system, photodiode array detector (CDAD, series G1315D) interfaced with an AC/DC convertor, an auto sampler (series GI239A) and HP chem. station (rev. B03.01) software package, a Rheodyne 7125 six ways injector with $10 \mathrm{ml}$ sample loap and Agilent Zorbax eclipse XXDB reversed phase C18 (150 X $4.6 \mathrm{~mm}$, particle size $5 \mathrm{um}$ ) analytical guard column (Agilent, USA). HPLC elution was done at room temperature $\left(23 \pm 2^{\circ} \mathrm{C}\right)$ by solvent $\mathrm{A}$ (acetonitrile) and solvent B (acetic acid and water $2: 98 \mathrm{v} / \mathrm{v} \mathrm{ratio}$ ) at a flow rate of $0.8 \mathrm{ml} / \mathrm{min}$. with the following linear grading program, $100 \%$ B to $85 \%$ B for $30 \mathrm{~min}$., $85 \%$ B to $50 \%$ B for $20 \mathrm{~min}$., $50 \%$ to $0.0 \% \mathrm{~B}$ for $10 \mathrm{~min}$. and $0.0 \%$ to $100 \% \mathrm{~A}$ for 10 min. The chromatogram was simultaneously monitored at 280 and $230 \mathrm{~nm}$. (with $2 \mathrm{~nm}$. band width). The spectra was taken continuously through the elution. Calculation of the concentration was based on the external standard method of an aqueous solution containing the following phenolic standards; gallic, protochatchuic, gentisic, chlorogenic, caffeic, syrngic, vanillic, ferulic, sinapic, ellagic, rosemarinic, cinnamic acid, catachine and chyrsin to fit a standard curve (peak area versus concentration in $\mu \mathrm{g} / \mathrm{g}$ ) with lineary regression for each individual compound.

\section{Antioxidant activity:-}

It was determined by two methods.

1) 1,1diphenyl 2-picrylhydrazine (DPPH) radical scavenging assay:- It was used according to Hwang and Do-Thi (2014). This method based on the evaluation of the free radicals scavenging effect on DPPH. The extracted sample was diluted with extraction buffer and $400 \mu \mathrm{l}$ aliquot was mixed with 
$200 \mu \mathrm{l}$ of $0.5 \mathrm{mM}$ DPPH in methanol and the absorbance was measured at $517 \mathrm{~nm}$. against a blank of pure methanol after $60 \mathrm{~min}$. of incubation in a dark condition using UV-VIS spectrophotometer (Laxco-Alpha-1102, suit).

2)Radical ABTS*scavenging activity:- Antioxidant activity was quantified by dying assay of the radical cution 2,2-Azino-Bis-3-Ethylbenzothiazoline-6 Sulfonic Acid (ABTS*) according to Hwang and Do-Thi (2014). Equal quantities of a $7 \mathrm{mM}$ aqueous solution of ABTS* was mixed with $2.45 \mathrm{mM}$ potassium persulfate for $16 \mathrm{~h}$. at room temperature $\left(23 \pm 2^{\circ} \mathrm{C}\right)$ in the dark to prepare stock solution of ABTS*. One $\mathrm{ml}$ of the stock solution was diluted with $60 \mathrm{ml}$ of ethanol: water $(50: 50, \mathrm{v} / \mathrm{v})$ to obtain an absorbance of $1.0 \pm 0.02$ at $734 \mathrm{~nm}$ using UVVIS spectrophotometer (Laxco-Alpha-1102, suit). To $50 \mu \mathrm{l}$ of the sample ethanol extract, $4.95 \mathrm{ml}$ of the ABTS* solution was added and left for 1 hour in a dark. Then the absorbance was measured at 734 $\mathrm{nm}$. using the above spectrophotometer.

\section{Nutritional quality:-}

1)Amino acid composition:- Fifty milligrams of the chia seed meal were mixed with $10 \mathrm{ml}$ of $6 \mathrm{~N}$ hydrochloric acid containing $50 \mu 1$ marcapto ethanol in heat-resistant tube. The tubes were sealed, heated in oven at $110^{\circ} \mathrm{C}$ for $24 \mathrm{~h}$., then cooled to room temperature and filtered through Whatman No. 1 filter paper. Both tube and the precipitate were washed with distilled water. The washed water was added to the previous filtrate then completed to 25 $\mathrm{ml}$ in a volumetric flask. Five $\mathrm{ml}$ of the filtrate were transformed to $25 \mathrm{ml}$ beaker and placed in a vacuum desiccator until dryness in presence of potassium hydroxide. The dried residue was dissolved in one $\mathrm{ml}$ of sodium citrate buffer ( $\mathrm{pH} 2.2$ ) and analyzed by the Bechman Amino acid analyzer model 119CL (Duranti and Cerletti, 1979).

2)In-vitro protein digestibility (IVPD):-Pepsin followed by pancreatin digestion procedure was used as described by Ali (1999). Two hundred and fifty $\mathrm{mg}$ of the defatted ground chia seed flour were suspended in a conical flask containing $15 \mathrm{ml}$ of 0.1 $\mathrm{N}$ hydrochloric acid in which $1.5 \mathrm{mg}$ of pepsin was dissolved. The mixture was gently shaken then incubated at $37^{\circ} \mathrm{C}$ for $3 \mathrm{~h}$. in an incubator shaker. The incubated solution was neutralized with $0.5 \mathrm{~N}$ sodium hydroxide and treated with $4 \mathrm{mg}$ of pancreatin dissolved in $7.5 \mathrm{ml}$ of $0.2 \mathrm{M}$ phosphate buffer ( $\mathrm{pH} 0.8$ ) containing $0.05 \mathrm{M}$ sodium azide as antimicrobial. The resulted mixture was gently shaken and incubated for $24 \mathrm{~h}$. at $37^{\circ} \mathrm{C}$. At the end of incubation period, $4 \mathrm{ml} \mathrm{30 \%} \mathrm{trichloroacetic} \mathrm{acid}$
(TCA) was added to stop the reaction. The digest mixture was kept for $1 \mathrm{~h}$. at room temperature (23 $2^{\circ} \mathrm{C}$ ) to precipitate the undigested protein, then centrifuged at $6000 \mathrm{rpm}$ for $20 \mathrm{~min}$. Soluble protein content was determined by micro-Kjeldahl method and the IVPD was calculated from the following equation;

$$
\% \text { IVPD }=\frac{\text { Protein content in the supernatant }}{\text { protein content in the sample }} \times \mathbf{1 0 0}
$$

3)Computed-protein efficiency ratio (C-PER):Computed-protein efficiency ratio was calculated by the procedure of Khattab (2004). C-PER was calculated according to the following regression equations:

$$
\begin{aligned}
& \text { PER }_{A}=-0.684+0.456 \text { Leu }-0.047 \text { Pro. } \\
& \text { PER }_{B}=-0.468+0.454 \text { Leu }+0.105 \text { Tyr. } \\
& \text { PER }_{C}=-1.816+0.435 \text { Met }+0.780 \text { Leu }+0.211 \\
& \text { His }-0.944 \text { Tyr. }
\end{aligned}
$$

All amino acids used were $\mathrm{g}$ per $100 \mathrm{~g}$ protein and the mean of the three equations was taken as the C-PER value of the sample.

4)Computed-biological value of protein (C-BV):Biological value of chia seed protein was calculated according to Khattab (2004). Using the following regression equation:

$$
\mathrm{BV}(\%)=39.55+8.89 \times \text { lysine }(\mathrm{g} / 100 \mathrm{~g} \text { protein })
$$

Functional properties:- Water and oil holding capacities were determined according to the method of Capitani et al. (2013) using one gram of defatted chia seed flour, $10 \mathrm{ml}$ distilled water or $10 \mathrm{ml}$ refined corn oil. The emulsification capacity was determined at room temperature as mentioned by Attia (1987) using one gram sample, $12 \mathrm{ml}$ of distilled water, refined corn oil and blending until the emulsion break point was reached (phase separation into 2 layers visually). Emulsification capacity is expressed as $\mathrm{ml}$ oil emulsified by $100 \mathrm{~g}$ sample. The foam capacity and stability were determined by the procedure of Ali (1999) using 3 grams of samples, $100 \mathrm{ml}$ distilled water and blending for $5 \mathrm{~min}$. at room temperature $\left(23 \pm 2^{\circ} \mathrm{C}\right)$. The suspension along with foam was poured into $200 \mathrm{ml}$ graduated measuring cylinder and the total volume was recorded after $30 \mathrm{sec}$. The volume of the foam capacity was calculated after $30 \mathrm{sec}$. and recorded as foam capacity (FC) according to the following formula;

$$
\begin{aligned}
& \text { \%Volume increase or foam capacity }= \\
& \frac{\text { Total wolume-Initial volume }}{\text { Initial wolume }} \times \mathbf{1 0 0}
\end{aligned}
$$

The foam volume was recorded after $0,5,10,15,30$, 45 and $60 \mathrm{~min}$. of standing at room temperature ( $23 \pm$ $2{ }^{\circ} \mathrm{C}$ ) in the cylinders as foam stability according to the following equation; 
Foam stability $(\mathrm{ml})=$ Total volume - Liquid volume

Technological methods:-

Biscuits preparation:- Both control and chia-enriched biscuits were prepared as mentioned by Mesías et al. (2016). Control biscuit was formulated with wheat flour (130 g), sucrose (35 g), distilled water (30 g), sunflower oil (26 g), sodium bicarbonate $(0.8 \mathrm{~g})$, ammonium bicarbonate $(0.4 \mathrm{~g})$ and salt $(1 \mathrm{~g})$. Also, biscuits were formulated after replacing wheat flour with $5 \%$ of either defatted high protein fraction and/or high dietary fiber fraction chia seed flour. Accordingly, 3 types of biscuits were prepared; (A) control, free from chia seed meal flour, (B) containing 5\% high protein meal fraction and (C) containing 5\% high fiber meal fraction. The prepared biscuits dough was left for $60 \mathrm{~min}$. in polyethylene bags before forming into bars and baking at $210^{\circ} \mathrm{C}$ for $8-10$ min.in an electric oven (G.E.C. QA50QV I5A35OV). After cooling biscuit was packed in polyethylene bags and after $24 \mathrm{~h}$. of baking, biscuits weight, thickness, length and wide were measured as mentioned above.

Sensory evaluation:- The prepared biscuits were subjected for sensory evaluation, using ten panelists of the Food Science and Technology Department, Faculty of Agriculture, Alexandria University, Alexandria, Egypt. Each panelist was asked to evaluate the biscuit properties according to descriptive sheets described by Arbeitsgemeishaft Getreideforschung (1978) method.

Statistical analysis:- Results were analyzed for statistical significance at $\mathrm{P} \leq 0.05$ by student's t-test using statistical package for social sciences software (SPSS) version 22 (2018).

\section{RESULTS AND DISCUSSION}

\section{Defatted chia seed flour}

A.Proximate composition:- Data in Table (1) reveal that, extraction of oil caused an increase in protein, ash, crude fibers and nitrogen free extract from 26.1 to $41.14,5.15$ to $8.27,22.22$ to 35.03 and 9.96 to $15.56 \%$, respectively in local, from 27.89 to 44.41 , 4.8 to $7.64,24.31$ to 38.86 and 5.8 to $9.09 \%$, respectively in imported chia meals. This means that protein and crude fibers are the main components of chia seed meal. They represent more than $75 \%$ of the meal components. The ratio between both components was ranged from 1.1-1.2 protein to 1 crude fiber. Therefore, chia seed meal flour is a good source of protein and fibers. Ullah et al. (2016) showed that defatted chia seed flour contains from 34 to $40 \%$ of dietary fiber. This amount is equal to $100 \%$ of the daily recommendations for adults to decrease the risk of coronary heart disease, diabetes mellitus type 2 and several types of cancer (Amato $e t$ al., 2015).

B.Dietary fibers :- As shown from the results in Table (1), defatted chia seed flour contained high level of total dietary fiber. This component was $57.7 \%$ in local and $55.8 \%$ in imported defatted chia seed. It was composed of 53.3 and $48.2 \%$ insoluble dietary fiber (IDF), 4.4 and $7.6 \%$ soluble dietary fiber (SDF) in local and imported defatted chia seed flour, respectively. This amount and types of dietary fiber are higher than those mentioned for flaxseed $(27.3 \%$ TDF), amaranth (6.7\% TDF), quinoa (7\% TDF), peanut (8.8\% TDF) and soybean (9.6\% TDF). Generally, SDF forms part of chia seed mucilage.

The IDF to SDF ratio is an important index for certain food application. This ratio (IDF/SDF) is nearly 12.11:1 and 6.34:1 in defatted local and imported defatted chia seeds flour, respectively. According to Spiler (1986) IDF/SDF ratio from $1: 2.2$ is the most advantageous factor for the beneficial physiological effects. Generally, the high of IDF in defatted chia seed meal suggests possible application in dietetic physiological products. Intake this type of fiber is linked to a sensation of satiety, since as the fiber absorbs water, swells and fills stomach and reduces from the consumed food. It is also, increased the volume and weight of the fecal mass, improved digestive process and prevented constipation and colon cancer (Alfredo et al., 2009).

Chia seed meal contained high amount of neutral detergent fiber (NDF), 43-47.2\% and low level of acid detergent fiber (ADF), 34-36\%. This means that dietary fiber of chia seed had more cell wall materials including pectin (IDF) than cellulose and lignin. The difference between NDF and ADF gives the hemicellulose (Dick et al., 2015).

Table 1.Proximate composition and dietary fiber of chia (Salvia hispanica $\mathrm{L}$.) seeds defatted flour

\begin{tabular}{ccc}
\hline $\begin{array}{c}\text { Component }(\% \text { on dry } \\
\text { weight) }\end{array}$ & $\begin{array}{c}\text { Local } \\
\text { chia }\end{array}$ & $\begin{array}{c}\text { Imported } \\
\text { chia }\end{array}$ \\
\hline Crude protein & 41.14 & 44.41 \\
Ash & 8.27 & 7.64 \\
Crude fiber & 35.03 & 38.86 \\
Nitrogen free extract(NFE*) & 15.56 & 9.09 \\
Soluble dietary fiber (SDF) & 4.40 & 7.60 \\
Insoluble dietary fiber(IDF) & 53.30 & 48.20 \\
Total dietary fiber(TDF) & 57.70 & 55.80 \\
Neutral detergent fiber (NDF) & 47.20 & 43.00 \\
Acid detergent fiber (ADF) & 36.00 & 34.20 \\
\hline *NFE was calculated by difference. & &
\end{tabular}




\section{C.Nutritional quality:-}

1)Amino acids:-The amino acid pattern of local and imported defatted whole chia seed flour in Table (2) was nearly similar. Both local and imported chia meal had eight essential amino acids. These acids can be arranged according to their concentration in the following decreasing order, leucine, phenylalanine, lysine, valine, sulfur containing amino acids, isoleucine, therionine and histidine, respectively. Among non-essential amino acids, glutamic acid found at high concentration followed by argnine, aspartic acid, alanine, glycine, tyrosine, serine and proline. Generally, glutamic acid considered an important amino acid in the diet. It is able to modulate imm-regulatory response and enhances athletic performance. Also, arginine plays role in preventing heart diseases (Timilsena et al., 2017).

2)Protein digestibility:- The in vitro protein digestibility (IVPD) of the defatted chia seed flour was low, (Table 2). It was very close in both local $(66.5 \%)$ and imported $(66.97 \%)$ chia seed defatted flour. This may be due to their high fiber content in addition to presence of other antinutritional factors such as polyphenols. Sandoval-Oliveros and Paredes-Lopez (2013) found that IVPD of defatted chia seed flour ranged from $77.5 \%$ to $78.9 \%$. In contrast, Timilsena et al. (2016) reported that IVPD of chia seeds ranged from $49.4 \%$ to $78.9 \%$.

3)Computed protein efficiency ratio (C-PER) and computed biological value of protein $(\mathrm{C}-\mathrm{BV})$ :- $\mathrm{C}$ PER and C-BV of the defatted local and imported chia seed flour were varied from 1.1 to 1.3 and 69.4 to 71.6, respectively, (Table 2). Both of these nutritional parameters were based on the amino acids content of chia seeds. The low value of these parameters due to the limiting amino acids in chia seeds threonine, methionine, lysine, leucine and histidine (Weber et al., 1991).

\section{D.Phenolic content and antioxidant activity:}

1)Total phenolic content:- Many of polyphenolic compounds exert a marked protective effect on plant lipids especially that containing high concentration of polyunsaturated fatty acids (PUFA) such as chia seeds. As shown from Table (3) the total phenolic content $(\mathrm{mg} / \mathrm{g})$ as gallic acid equivalent (GAE), was higher in local $(1.42 \mathrm{mg} / \mathrm{g})$ than imported $(1.1 \mathrm{mg} / \mathrm{g})$ chia seed defatted flour. These components are responsible to prevent the chia seed lipids oxidation. Reyes-Caudillo et al. (2008) found that the total phenolic content in chia seeds ethanol extract was $8.8 \%$ on dry weight basis.

Table 2. Nutritional quality of chia (Salvia hispanica L.) seeds defatted flour

\begin{tabular}{|c|c|c|}
\hline Parameter & Local Chia & Imported Chia \\
\hline \multicolumn{3}{|l|}{ 1-Amino acids (g/100 g protein) } \\
\hline \multicolumn{3}{|l|}{ a-Essential amino acid } \\
\hline Leucine & 4.34 & 4.82 \\
\hline Phenylalanine & 3.46 & 3.84 \\
\hline Lysine & 3.36 & 3.60 \\
\hline Valine & 2.97 & 3.68 \\
\hline Sulfur containing amino acids & 2.75 & 2.36 \\
\hline Isoleucine & 2.35 & 2.63 \\
\hline Therionine & 2.20 & 2.46 \\
\hline Histidine & 2.04 & 2.15 \\
\hline \multicolumn{3}{|l|}{ b-Non-essential amino acid } \\
\hline Glutamic acid & 12.36 & 13.03 \\
\hline Argnine & 7.20 & 7.42 \\
\hline Aspartic acid & 5.74 & 6.40 \\
\hline Alanine & 3.33 & 4.39 \\
\hline Glycine & 2.92 & 3.39 \\
\hline Serine & 2.84 & 2.94 \\
\hline Proline & 2.82 & 2.89 \\
\hline Tyrosine & 2.70 & 3.06 \\
\hline 2-In vitro protein digestibility (IVPD) (\%) & 66.50 & 66.97 \\
\hline 3- Computed- protein efficiency ratio (C-PER) & 1.30 & 1.10 \\
\hline 4- Computed- biological values (C-BV) (\%) & 69.40 & 71.60 \\
\hline
\end{tabular}


Taga et al. (1984) showed that the presence of polyphenols indicates that chia seeds possess natural antioxidants in appreciable quantity. Viladomiu et al. (2013) mentioned that phenolic compounds in plants have several functions such as attracting insects, protection against UV-radiation, regulating osmotic pressure and exhibiting an astringent effect. It has also an advantageous effect on human health, as inhibiting enzymes involved in oxidation reaction or scavenging free radicals. According to Hernandez (2012) chia seed had high values of phenolic compounds.

2)Identification and quantification of simple phenolic compounds:- Table (3) gives the concentration (ug/g) of the individual phenolic compounds identified in local and imported defatted chia seeds flour. The levels reported in this work represent only the free forms of phenolic compounds since no hydrolysis was carried out to the sample before HPLC analysis. These compounds were found in defatted flour of both local and imported chia seeds. They can be classified into 3 groups according to their concentrations. Group one includes the major components which found up to $100 \mathrm{ug} / \mathrm{g}$. This group formed from caffeic acid, gentisic, rosmarinic, cteachin and rutin. Second group contains the compounds with the levels ranges from 20 to 100 $\mathrm{ug} / \mathrm{g}$. It is included ferulic acid and gallic acid. The last group includes the other phenolic compounds less than $20 \mathrm{ug} / \mathrm{g}$. Crosby (2005) found that chia seed contained caffeic acid, chlorogenic acid, quercetin, phenolic glycoside $\mathrm{K}$ and glycoside Q in appreciable amounts. Reyes-Caudillo et al. (2008) showed that chia seed with a wide range of antioxidant compounds can be regarded as a great source of antioxidant. Ullah et al. (2016) found that addition of $750 \mathrm{ppm}$ chia seed methanol extract had significant effect to prolong the shelf stability of winterized cotton seed oil at ambient temperature.

3)Antioxidant activity:- The results of the antioxidant activity measured by two methods, namely DPPH and ABTS of the local and imported defatted chia seed flour presented in Table (3). Generally, the antioxidant activity of the ethanolic extract of defatted local chia seed flour was relatively higher by the previous two mentioned methods than imported one. The same observation was reported above for total phenolic compounds of both seeds.

Table 3.Total phenolic content, simple phenolic compounds and antioxidant activity of chia (Salvia hispanica L.) seeds defatted flour

\begin{tabular}{ccc}
\hline Parameter & Local chia & Imported chia \\
\hline 1- Total phenols as GAE (mg/g) & 1.42 & 1.01 \\
\hline 2- Phenolic compound (ug/g) & & \\
Caffeic acid & 252.39 & 284.04 \\
Gentisic & 209.95 & 220.67 \\
Rosmarinic & 138.12 & 134.63 \\
Cteachin & 136.79 & 92.37 \\
Rutin & 92.58 & 217.70 \\
Ferulic acid & 24.96 & 46.69 \\
Gallic acid & 21.90 & 38.71 \\
Vanillic acid & 15.86 & 11.37 \\
Cinnamic acid & 12.42 & 7.00 \\
P-hydroxybenzoic & 5.91 & 12.65 \\
Apigenin & 4.97 & 5.30 \\
P-coumaric acid & 4.27 & 12.33 \\
Apigenin-7-glucoside & 2.87 & 1.62 \\
Chrysin & 1.44 & 0.94 \\
Sinapic acid & 0.67 & 0.82 \\
Syringic acid & 0.53 & 0.72 \\
Kaempferol & 0.39 & 2.08 \\
Quercetin & 0.27 & 1.25 \\
Protocatechuic acid & 0.00 & 3.26 \\
\hline 3- Antioxidant activity TE* mg/g & & \\
DPPH & 1.85 & 1.68 \\
ABTS & 1.75 & 1.45 \\
\hline
\end{tabular}

*(TE) Trolox equivalent. 
This activity of chia seed phenolic compounds is mainly due to their redox properties which allow them to act as reducing agents, hydrogen donors, singlet oxygen quenchers and metal chelators. Ullah et al. (2016) reported that the antioxidant activity of chia seed was greater than Moringa olifera, sesame cake extracts and similar to that high tannin sorghum varieties. It protects chia seeds from oxidative deterioration. Taga et al. (1984) attributed the high antioxidant activity of chia seed extract to its content of caffeic acid than other flavonols compounds such as myricetin and quercetin. Alfredo et al. (2009) showed that intake $7 \mathrm{~g}$ of the fiber rich fraction of chia seed meets the total need of dietary antioxidant activity level.

E.Functional properties:-The results of these properties were tabulated in Table (4).

1)Water holding capacity (WHC):- As shown from Table (4) both local and imported chia seed defatted flour are able to hold high amount of water. This may be due to the presence of SDF, mucilage and high protein level and its content of available polar amino acids which contain the primary sites for water binding. Vázquez-Ovando et al. (2013) reported that due to high water holding capacity of defatted chia seed flour, it is suitable to add in products requiring hydration, viscosity development and conservation of freshness such as baked products.

2)Oil holding capacity (OHC):- The oil absorption of chia seeds defatted flour was high. This is mainly due to the nonpolar sites of the amino acids in chia seed protein. Vázquez-Ovando et al. (2009) stated that small particle size of the flour have relatively more contact surface to hold more oil.

3)Emulsification capacity (EC):- Result in Table (4) indicates that the emulsification capacity of chia seed defatted flour was up to $50 \mathrm{ml} / 100 \mathrm{~g}$. This is agreed with that mentioned by Alfredo et al. (2009). They found that emulsifying activity of chia seed defatted flour was $53.26 \mathrm{ml} / 100 \mathrm{~g}$. Generally, this property is based on protein configuration, content and its hydrophobic groups. The increase of the exposed area of hydrophobic groups, required to bind oil, on the protein surface increases from the interacting with the oil phase.

4)Foaming properties:- Foaming capacity (FC) of chia seed defatted flour was low $18-20 \%$ in local and imported seeds, ( Table 4). This may be due to weak an adequate balance between hydrophobicity and hydrophilicity, which is required to save the responsible amount of free energy of foam stability.
The foam stability (FS) was decreased slowly upon standing at room temperature Table (4). The instability of foams is due to the drainage of liquid from lamellase and the rupture in cell wall of the bubbles (Sosulski et al., 1976).

Table 4.Functional properties of chia (Salvia hispanica $\mathrm{L}$.) seeds defatted flour

\begin{tabular}{lcc}
\hline \multicolumn{1}{c}{ Property } & $\begin{array}{c}\text { Local } \\
\text { chia }\end{array}$ & $\begin{array}{c}\text { Imported } \\
\text { chia }\end{array}$ \\
\hline WHC $^{*}$ (g water/g sample) & $8.5 \pm 0.02$ & $7.5 \pm 0.01$ \\
OHC $^{*}$ (g oil /g sample) & $5.1 \pm 0.01$ & $5.3 \pm 0.01$ \\
EC $^{*}$ (ml oil /100 g sample & $52 \pm 0.05$ & $55 \pm 0.05$ \\
FC* (\%) & $20 \pm 0.5$ & $18 \pm 0.5$ \\
FS $^{*}$ (\%) after (min.) & & \\
0 & 20 & 18 \\
5 & 12 & 18 \\
30 & 8 & 6 \\
45 & 8 & 6 \\
60 & 8 & 6 \\
\hline
\end{tabular}

* WHC: Water holding capacity, OHC: Oil holding capacity, EC: Emulsification capacity, FC: Foaming capacity and FS: Foam stability.

F.Fractionation:- Dry fractionation of the defatted chia seed flour by screening through 100 mesh sieve was done to obtain two fractions, one high in protein (down 100 mesh) and the other rich in fiber (up to 100 mesh) . Fig. (1) illustrates variation in the appearance and shape of the two fractions according to their particle size and content of other component than crude oil.

Results in Table (5) indicated that the neutral detergent fiber (NDF), acid detergent fiber (ADF) and hemicellulose ranged from 86.5 to $90.7,49.01$ to 54 and 37.49 to $36.7 \%$, respectively in high fiber fraction of local and imported chia seeds meal. In contrast, there is no much differences were observed in other determined components either in high protein and/or in high dietary fiber fractions. Vázquez-Ovando et al. (2013) fractionated chia seeds flour into fiber and protein rich fractions using dry fractionation process. The fiber rich fraction had high insoluble dietary fibers content $(53.45 \%)$ and good functional properties particularly water and oil holding capacities. The protein rich fraction had high essential sulfur amino acids and non-essential amino acids as well as protein content (44.6\%) with good functional properties similar to those of fiber rich fraction.

According to these results, chia seed meal fibrous fraction can use as an ingredient in dietetic product 


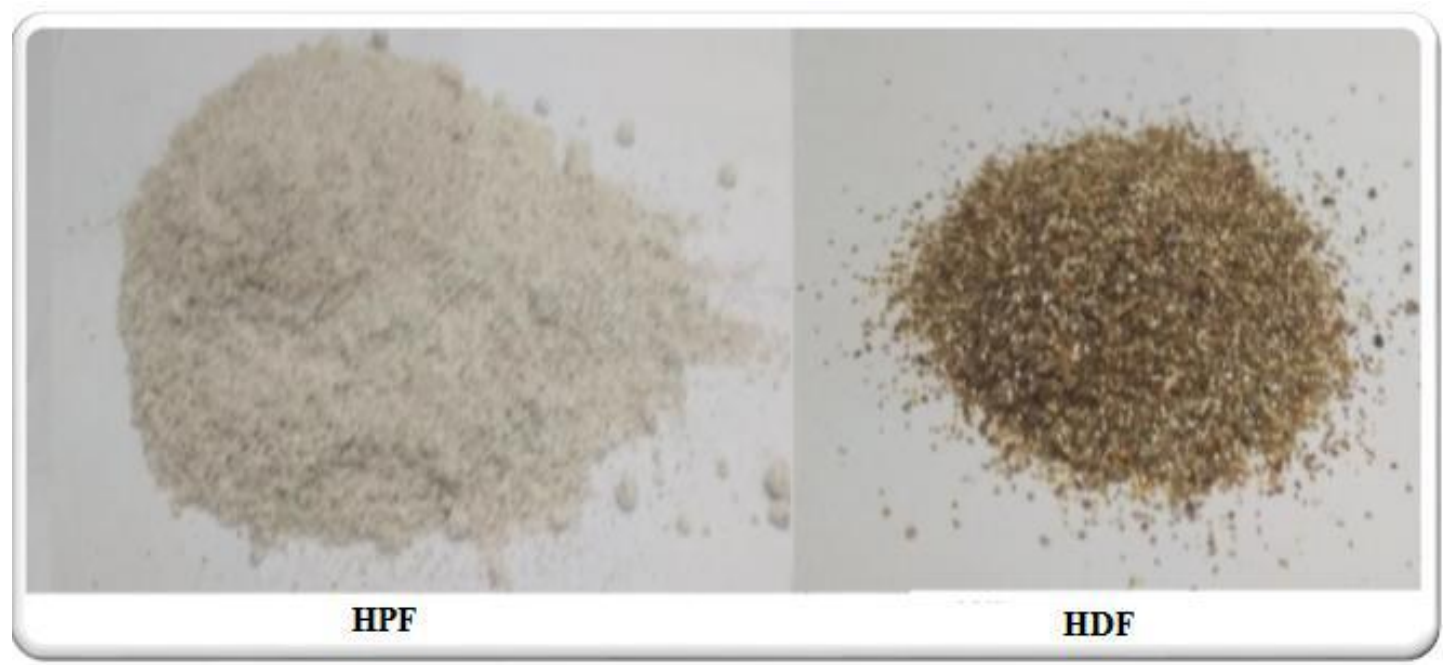

Fig.1. Appearance of high protein (HPF) and high dietary fiber (HDF) fractions of chia (Salvia hispanica L.) seeds meal.

Table 5.Protein and dietary fiber contents of high protein and high fiber fractions of defatted chia (Salvia hispanica L.) seeds flour

\begin{tabular}{lcccc}
\hline Component \% & \multicolumn{2}{c}{ Local chia } & \multicolumn{2}{c}{ Imported chia } \\
\cline { 2 - 5 } & (A) & (B) & (A) & (B) \\
\hline Crude protein & 41.50 & 11.80 & 45.50 & 13.80 \\
Neutral detergent fiber & 51.20 & 86.50 & 53.70 & 90.70 \\
Acid detergent fiber & 25.66 & 49.01 & 28.00 & 54.00 \\
Hemicellulose & 25.54 & 37.49 & 25.70 & 36.70 \\
\hline
\end{tabular}

(A) High protein fraction (HPF)

(B) High dietary fiber fraction (HDF)

such as baked and fried foods. Meanwhile, the protein rich fraction could be used as a potential food ingredient in emulsion foods.

G.Utilization in food purposes:-Three types of biscuits were prepared; (A) control made of $100 \%$ wheat flour; (B) product made of $95 \%$ wheat flour with 5\% high protein chia seed meal fraction (high protein biscuit) and (C) biscuit prepared from 95\% wheat flour with $5 \%$ high fiber chia seed meal fraction (high fiber biscuit). Data in Table (6) show the physical properties and sensory characteristics of these products. Length and weight of the biscuit products, containing 5\% high protein and 5\% high fiber chia seed meal were slightly reduced than control. The addition of both fractions caused a low reduction or dilution in wheat flour gluten. Presence of mucilage and fiber in both chia seed fractions help in keeping the dimension and weight of biscuits nearly close to the control product. Svec et al. (2016) found that addition of $10 \%$ chia seed flour to wheat flour during bread production caused gluten protein dilution and a decrease in bread volume.

The panelists accepted the three types of biscuit. They observed that using chia seed at 5\% level either as high protein and/or high fiber fractions caused changes in breakness from slightly tender to crispy, texture from fine to moderate, chewiness from excellent to good and taste from excellent to good. The control product was the superior and the other products were equal in the degree of acceptability. According to Mesías et al. (2016) adding chia seed flour in wheat based biscuit formulation enhanced the nutritional quality of this product, increasing protein, dietary fiber, antioxidants and polyunsaturated fatty acids. The latter component accelerates lipid oxidation in biscuits enriched with high amount of chia seed and that reducing its shelf life. 
Table 6.Physical and sensory characteristics of biscuits free and containing $5 \%$ of each of high protein and high fiber fractions of defatted chia seed flour.

\begin{tabular}{|c|c|c|c|c|c|c|c|c|c|c|c|}
\hline \multirow[b]{2}{*}{ Biscuit type } & \multicolumn{4}{|c|}{ Physical properties } & \multicolumn{7}{|c|}{ Sensory characteristics } \\
\hline & $\begin{array}{l}\text { Length } \\
(\mathrm{cm})\end{array}$ & $\begin{array}{l}\text { Width } \\
\text { (cm) }\end{array}$ & $\begin{array}{l}\text { Thickness } \\
\text { (cm) }\end{array}$ & $\begin{array}{c}\text { Weight of } 10 \\
\text { pieces (g) }\end{array}$ & $\begin{array}{c}\text { General } \\
\text { appearance }\end{array}$ & $\begin{array}{c}\text { Surface and } \\
\text { bottom } \\
\text { characteristics }\end{array}$ & Leavening & Breakness & Texture & Chewiness & Taste \\
\hline $\begin{array}{l}100 \% \text { wheat flour } \\
\text { biscuit }\end{array}$ & 10 & 3 & 0.5 & 220 & Excellent & Slightly bubbled & $\begin{array}{c}\text { Very } \\
\text { leavening }\end{array}$ & $\begin{array}{l}\text { Slightly } \\
\text { tender }\end{array}$ & Fine & Excellent & Excellent \\
\hline High protein biscuit & 9.8 & 3 & 0.5 & 218 & Excellent & Slightly bubbled & $\begin{array}{c}\text { Very } \\
\text { leavening }\end{array}$ & Crispy & Moderate & Good & Good \\
\hline High fiber biscuit & 9.9 & 3 & 0.5 & 219 & Excellent & Slightly bubbled & $\begin{array}{c}\text { Very } \\
\text { leavening }\end{array}$ & Crispy & Moderate & Good & Good \\
\hline
\end{tabular}




\section{CONCLUSION}

The above results showed that chia seed (Salvia hispanica L.) meal as a source of protein, dietary fibers and polyphenols is promising as functional ingredients in preparing food products.

\section{REFERENCES}

Alfredo, V., R. Gabriel, C. Luis and B. David.2009.Physicochemical properties of a fibrous fraction from chia seed (Salvia hispanica L.). LWT-Food Science and Technology. 42:168-173.

Ali, G.H. 1999. Utilization of Guava and Mandarin Seeds as Potential Sources of Oil and Protein. M.Sc. Thesis, Food Science and Technology Department, Faculty of Agriculture, Alexandria University, Alexandria, Egypt.

Amato, M., M. C. Caruso, F. Guzzo, F. Galgano, M. Commisso, R. Bochicchio and F. Favati .2015. Nutritional quality of seeds and leaf metabolites of chia (Salvia hispanica L.) from southern Italy. European Food Research and Technology. 241: 615-625.

Arbeitsgemeishaft Getreideforschung.1978. Standard Methoden Für Getreide, Mehl und Bort (In German). $6^{\text {th }}$ ed. Verlag Moits Schafer, Dotmold, W. Germany.

AOAC. 2000. Official Methods of the Association of the Official Analytical Chemists. Maryland, USA.

AOAC. 2003. Official Methods of the Association of the Official Analytical Chemists. Virginia, DC, USA.

Attia, R. S. 1987. Chemical and Technological Studies on Rapseeds and Rapseed oil. M.Sc. Thesis, Food Science and Technology Department, Faculty of Agriculture, Alexandria University, Alexandria, Egypt.

Ayerza, R., W. Coates and M. Lauria.2002. Chia seed (Salvia hispanica L.) as an $\omega-3$ fatty acid source for broilers: influence on fatty acid composition, cholesterol and fat content of white and dark meats, growth performance and sensory characteristics. Poultry Science. 81:826-837.

Bresson, J.L., A. Flynn, M. Heinonen, K. Hulshof, H. Korhonen, P. Lagiou, M. Løvik, R. Marchelli, A. Martin, B. Moseley, H. Przyrembel, S. Salminen, J.J. Strain, S. Strobel, I. Tetens, H.V.D. Berg, H.V. Loveren and H. Verhagen. 2009. Opinion on the Safety of chia seeds (Salvia hispanica L.) and ground whole chia seeds as a food ingredient. European Food Safety Authority Journal.996:1-26.

Capitani, M. I., V. Y. Ixtaina, S. M. Nolasco and M. C. Tomas. 2013. Microestructure, chemical composition and mucilage exudation of chia (Salvia hispanica L.) nutlets from Argentina. Journal of the Science of Food and Agriculture. 93:3856-3862

Crosby, G. 2005. Lignans in food and nutrition. Food Technology. 59:32-36.

Dick, M., T.M.H. Costa, A. Gomaa, M. Subirade, A.D.O. Rios and S.H. Flo^res. 2015. Edible film production from chia seed mucilage: Effect of glycerol concentration on its physicochemical and mechanical properties. Carbohydrate Polymers. 130:198-205.
Duranti, M. and P. Cerletti. 1979. Amino acid composition of seed proteins of Lupinus albus. J. Agric. Fd. Chem. 27:977-978.

Guiotto, E.N., V.Y. Ixtaina, M.C. Tomás and S.M. Nolasco. 2011. Influence of moisture content on physical properties of chia (Salvia hispanica L.) seeds. Trans. ASABE. 54: 527-533.

Hernández, L.M. 2012. Mucilage from Chia Seeds (Salvia hispanica L.): Microstructure, Physico-Chemical Characterization and Applications in Food Industry. PhD Thesis. Escuela de Ingenieria. Pontificia Universidad, Catolica, de Chile.

Hwang, E. S. and N. Do-Thi. 2014. Effects of extraction and processing methods on antioxidant compound contents and radical scavenging activities of Laver (Porphyra tenera L.). Preventive Nutrition and Food Science.19: 4048.

Khattab, R.Y.I. 2004. Chemical and Technological Studies on Flaxseed to Improve Its Sensorial and Nutritional Properties in Foods. PhD Thesis. Food Science Department, Faculty of Agriculture Saba-Bacha, Alexandria University, Alexandria, Egypt.

Kim, K. H., R. Tsao, R. Yang and S. W. Cui. 2006. Phenolic acid profiles and antioxidant activities of wheat bran extracts and the effect of hydrolysis conditions. Food Chemistry. 95: 466-473.

Mesías, M., F. Holgado, G. Marquez-Ruiz and F.J. Morales. 2016. Risk/benefit considerations of a new formulation of wheat-based biscuit supplemented with different amounts of chia flour. Food Science and Technology. 73:528-535.

Michele, S.C. and M.S. Myriam. 2014. Chemical characterization of chia (Salvia hispanica L.) seed for use in food products. Journal of Food and Nutrition Research. 2:263-269.

Nielson, S.S. 2010. Food Analysis Laboratory Manual ( $2^{\text {nd }}$ Ed.). Springer Science, New York. pp. 17-47.

Orona-Tamayo, D., M. E. Valverde, B. Nieto-Rendo'n and O. Paredes-Lo'pez. 2015. Inhibitory activity of chia (Salvia hispanica L.) seed protein fractions against angiotensin Iconverting enzyme and antioxidant capacity. Food Science and Technology. 64: 236-242.

Pizarro, P.L., E.L. Almeida , A.S. Coelho, N.C. Sammán, M.D. Hubinger and Y.K.Chang. 2015. Functional bread with n-3 alpha linolenic acid from whole chia (Salvia hispanica L.) flour. Journal of Food Science and Technology. 52: 4475-4482.

Prosky, L. 2001. What is Dietary Fiber?. A New Look at the Definition. In " Advanced Dietary Fiber Technology". B. V. McCleary, \& L. Prosky (Eds.) Oxford: Blackwell Science Ltd. pp. 63-76.

Reyes-Caudillo, E., A. Tecante and M.A. Valdivia-López. 2008. Dietary fiber content and antioxidant activity of phenolic compounds present in Mexican chia (Salvia hispanica L.) seeds. Food Chemistry. 107:656-663. 
Sandoval-Oliveros, M.R. and O. Paredes-Lopez. 2013. Isolation and characterization of proteins from chia seeds (Salvia hispanica L.). Journal of Agricultural and Food Chemistry. 61:193-201.

Segura-Campos, M.R., I.M. Salazar-Vega, L.A. ChelGuerrero and D.A. Betancur-Ancona. 2013. Biological potential of chia (Salvia hispanica L.) seed protein hydrolysates and their incorporation into functional foods. Food Science and Technology. 50:723-731.

Sosulski, F.W, M.D. Carratt and A.E. Slinkard. 1976. Functional properties of ten legume flour. Food Science and Technology. 9:66-71.

Spiler, C.A. 1986. Suggestion for a Basis on Which to Determine a Desirable Intake of Dietary Fibers. In "Handbook of Dietary Fibers in Human Nutrition" Spiler, C.A. (Ed.) CRC. Press, Florida. pp. 281-283.

Svec, I., M. Hruskova and I. Jurinova. 2016. Pasting characteristics of wheat-chia blends. Journal of Food Engineering. 172:25-30.

Taga, M.S., E.E. Miller and D.E. Pratt. 1984. Chia seeds as a source of natural lipid antioxidants. Journal of American Oil Chemists Society. 61:928-931.

Timilsena, Y. P., R. Adhikarib, C. J. Barrow and B. Adhikari. 2016. Microencapsulation of chia seed oil using chia seed protein isolate-chia seed gum complex coacervates. International Journal of Biological Macromolecules. 52:554-563.

Timilsena, Y.P., J. Vongsvivut, R. Adhikari and B. Adhikari. 2017. Physicochemical and thermal characteristics of Australian chia seed oil. Food Chemistry. 228:394-402.
Ullah, R., M. Nadeem, A. Khalique, M. Imran, S. Mehmood, A. Javid and J. Hussain. 2016. Nutritional and therapeutic perspectives of chia (Salvia hispanica L.) seeds: a review. Journal of Food Science and Technology. 53:1750-1758.

Vázquez-Ovando, A., D. Betancur-Ancona and L. ChelGuerrero. 2013. Physicochemical and functional properties of a protein-rich fraction produced by dry fractionation of chia seeds (Salvia hispanica L.). Journal of Food. 11:75-80.

Vázquez-Ovando, A., G. Rosado-Rubio, L. Chel-Guerrero and D. Betancur-Ancona. 2009. Physicochemical properties of a fibrous fraction from chia (Salvia hispanica L.) seeds. LWT Food Science and Technology. 42: 168-173.

Vázquez-Ovando, J., J. Rosado-Rubio, L. Chel-Guerrero and D. Betancur-Ancona. 2010. Dry processing of chia (Salvia hispanica L.) seeds flour: Chemical characterization of fiber and protein. Journal of Food. 8:117-127.

Viladomiu, M., R. Hontecillas, P. Lu and J. Bassaganya-Riera. 2013. Preventive and prophylactic mechanisms of action of pomegranate bioactive constituents. Evidence-Based Complementary and Alternative Medicine. 2013:1-18.

Weber, C. W., H. S. Gentry, E. A. Kohlhepp and P. R. McCrohan. 1991. The nutritional and chemical evaluation of chia seeds. Ecology of Food and Nutrition. 26:119-125.

Zilic, S., A. Serpen, G. Akillioglu, M. Jankovic and V. Gokmen. 2012. Distributions of phenolic compounds, yellow pigments and oxidative enzymes in wheat grains and their relation to antioxidant capacity of bran and debranned flour. Journal of Cereal Science. 56: 652-658. 


\section{الملخص العربي}

\section{تقييم جريش" بذور الثيا (Salvia hispanica L. كمصدر للمكونات النشطة حيويا}

أسامة بكير ربيع محمد ، منى حسن حسين بخيت ، أمل محمد عبد الرازق، يحيى جمال الدين محرم

وغير الذائبة ( ) (

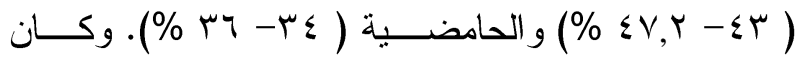
النشاط المضاد للأكسدة المقدر بطريقتين (ABTS , DPPH)

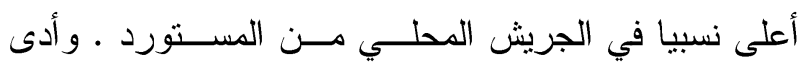
الفصل الجاف للجريش بمنخل . . 1 مش إلى الحصول على

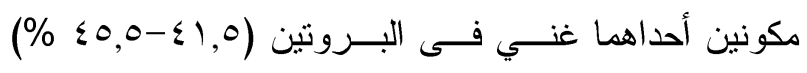

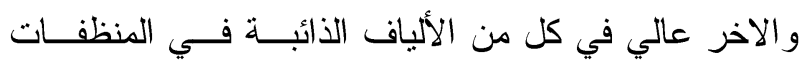

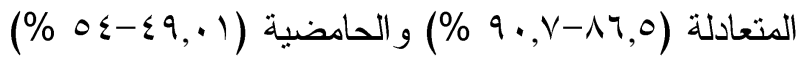
و الهيميسليلوز ( $)$ من الخواص الفيزيائية و الحسية لكل من البسكويت المحتوى على ه \% من مكون الجريش الغنى في البروتين والعــالي في الألياف. وأكدت النتائج نجاح استخدام جريش بذور الثيا

ومكوناته كمصدر و اعد لإعداد الأغذية الوظيفية. *جريش: ( دقيق بذور الثيا المستخلص منها الزيت) .
هدف البحث إلى تقييه جريش بذور الثــيا المصــرية

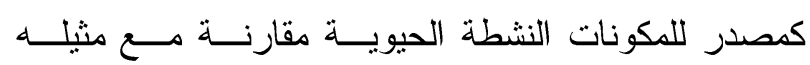

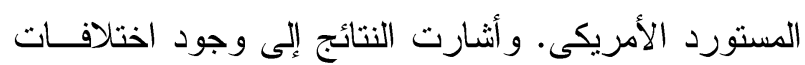

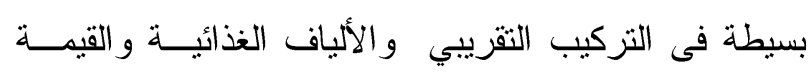

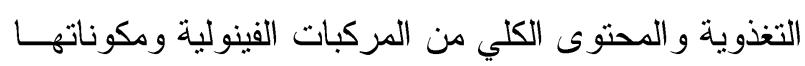
المفصولة باستخدام جهاز كرماتوجر افيا السائل عالي الأداء

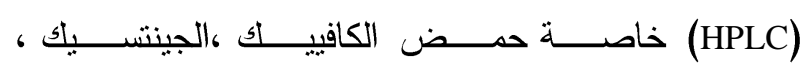
الروزمارينيكك،و الكتاكين بين جريش بذور الثــيا المحلــي

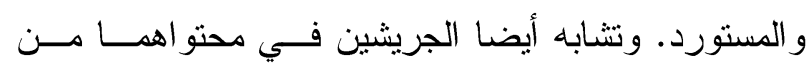

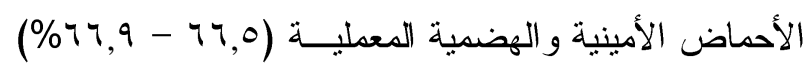

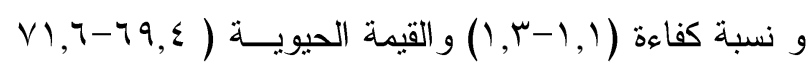
\%) للبروتين ،وقدرتهما العالية على ربط الماء (

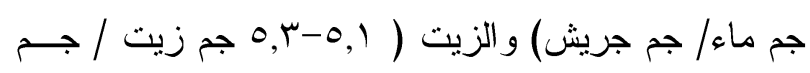

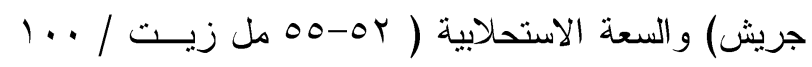

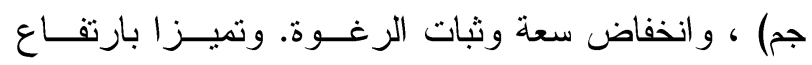

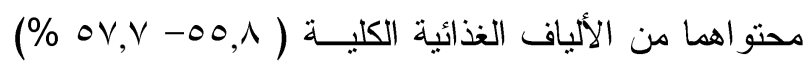

